\title{
Jeszcze o autentyczności dokumentu Jana XIII dla biskupstwa miśnieńskiego z 2 stycznia 968 roku
}

I.

Przeciwko tezom mojego artykułu o autentyczności bulli papieża Jana XIII z 2 I 968 r., ustanawiającej egzymowane biskupstwo miśnieńskie ${ }^{1}$, Dariusz Sikorski wysunął cały arsenał argumentów i uwag krytycznych ${ }^{2}$. W jego przekonaniu nie ulega wątpliwości, że rozważany dokument jest falsyfikatem. W konkluzji stwierdza: „Sądzę, że rzekomy dokument Jana XIII dla Miśni powstał jako fałszerstwo w pierwszej połowie XII w. (przed $1131 \mathrm{r}$.) w związku z większością tzw. fałszerstw miśnieńskich. Ponieważ w połowie XIII w. na nowo wybuchł spór o dziesięciny, starano się wzmocnić wymowę tego fałszerstwa przez uwierzytelnienie go w postaci widymusu".

Polemika D. Sikorskiego jest obszerna, niewiele krótsza od mojego artykułu. Zaatakowane zostało właściwie każde moje ustalenie. Nie wydaje się celowe, abym poszedł śladem Autora polemiki i z równym temperamentem wdawał się w spór o każde zdanie. Gęstwina faktów i przypuszczeń, która towarzyszyłaby takiej kontrpolemice, tylko zaciemniłaby obraz; w takiej sytuacji trudno byłoby odróżnić sprawy ważne od drugoplanowych, a przekonanie o słuszności argumentacji zależałoby głównie od użytej retoryki. Moją odpowiedź na polemikę D. Sikorskiego podzieliłem na trzy części; w pierwszej przytaczam przykłady świadczące o niewiarygodności stawianych mi zarzutów, w drugiej bronię najważniejszych z moich dotychczasowych argumentów, wykazując bezzasadność zarzutów, w trzeciej wreszcie przedstawiam zupełnie nowe dowody na autentyczność dokumentu miśnieńskiego.

D. Sikorski przeinacza mianowicie i zniekształca moje poglądy, a często przypisuje mi twierdzenia i ustalenia, których nigdy nie głosiłem. Niekiedy te zniekształcenia są drobne, a niekiedy, mówiąc kolokwialnie, wzięte z kapelusza. Ponadto D. Sikorski

${ }^{1}$ W. J a s i ń s k i, Bulla Jana XIII dla biskupstwa w Miśni z 2 stycznia 968 roku - falsyfikat czy autentyk? Przyczynek do studiów nad początkami Kościołów miśnieńskiego i poznańskiego, Roczniki Historyczne 79, 2013, s. 7-39. Dokumenty cesarskie cytuję z wydania w Monumenta Germaniae Historica, Diplomata regum et imperatorum Germaniae, t. I-II, Hannover 1879-1893 (w skrócie MGH DD ze wskazującą danego władcę syglą O I, O II, O III).

${ }^{2}$ D. A. S i k o r s k i, O rzekomej fundacji biskupstwa w Miśni 2 stycznia 968 roku, w niniejszym tomie Roczników Historycznych, s. 31-56. 
umieścił w swojej polemice szereg wypowiedzi erudycyjnych, które nie wnoszą nic istotnego do dyskusji, ale czytelnik może je jednoznacznie interpretować jako wytknięcie piszącemu te słowa braku podstawowej wiedzy. Ograniczam się do przedstawienia tylko kilku przykładów, gdyż omówienie wszystkich byłoby nadużywaniem cierpliwości czytelnika.

D. Sikorski (s. 32) przypisuje mi następujący pogląd: „Podobieństwa do datowanego na ten sam dzień dyplomu papieskiego (bez wątpienia autentycznego) dla opactwa w Hersfeld (cyt. dalej jako DH), w którym zostało ono egzymowane spod władzy miejscowego biskupa, wynikają z faktu, iż oba dokumenty przygotował ten sam kancelista Stefan, oraz z analogicznych - przynajmniej w zakresie odnoszącym się do klasztorów - rozporządzeń obu dokumentów papieskich". Nigdy nie twierdziłem, że wspomniane podobieństwa wynikają z faktu, że obydwa dokumenty przygotował skriniariusz Stefan. Było wprost odwrotnie, starałem się sprawdzić za pomocą analizy cursusu, czy dokumenty te mogły być napisane przez tę samą osobę. Nigdy też nie twierdziłem, że podobieństwo to wynika „z analogicznych rozporządzeń obu dokumentów". To ostatnie wyrażenie jest niejasne; nie użyłem w całym artykule ani razu słowa „rozporządzenia” i nie wiem, co D. Sikorski ma w tym wypadku na myśli.

D. Sikorski (s. 32) przypisuje mi też pogląd: „Zbieżności między DH [dokumentem hersfeldzkim] a DM [dokumentem miśnieńskim] są szczególnie uderzające dlatego, że DM przygotowano wyłącznie na podstawie już gotowego DH”. Również to zdanie jest nieporozumieniem, gdyż nigdy nie twierdziłem, że dokument miśnieński przygotowano wyłącznie na podstawie już gotowego dokumentu hersfeldzkiego. Przecież wyraźnie dowodziłem, że główna dyspozycja dokumentu miśnieńskiego opiera się na Pseudo-Izydorze, po niej następują liczne postanowienia dotyczące m.in. granic, dziesięcin Kościoła miśnieńskiego itd.; a więc nie ma mowy o żadnym „wyłącznie”.

D. Sikorski sugeruje (s. 32), że część argumentów za autentycznością dokumentu miśnieńskiego z 968 r. przejąłem z trwającej już 130 lat dyskusji, ale nie zauważyłem, że niektóre z tych starych argumentów „możemy obecnie łatwo zweryfikować, dysponując pełniejszą wiedzą”. Następnie dodaje: „Dotyczy to m.in. przytoczonej przez Autora opinii Karla Uhlirza z 1895 roku (s. 10), że jest mało prawdopodobne, aby fałszerz przeprowadził specjalną kwerendę poza Miśnią w celu znalezienia odpowiedniego dokumentu papieskiego, który mógłby wykorzystać do fałszerstwa”. D. Sikorski nie zauważył jednak, że argumenty K. Uhlirza referuję w części mojego artykułu poświęconej stanowi badań, jednak ani słowem nie piszę, że pogląd ten akceptuję.

Zdumiewają również kolejne fragmenty polemiki. D. Sikorski pisze (s. 35): „W. Jasiński milcząco przyjął, że dodane w DM słowa in Christo są typowe dla $\mathrm{X}$ w. (może temu celowi miało służyć stwierdzenie, że to "zwrot augustiański«)". Zwrot in Christo jest dość powszechny w średniowieczu, występuje też - jak pisze D. Sikorski - w dokumentach papieskich, aczkolwiek akurat nie w intytulacji (którą polemista pomylił zapewne z inskrypcją). Dlaczego określiłem go jako „augustiański”? Otóż cechą charakterystyczną tej frazy w dokumencie miśnieńskim jest to, że poprzedza ją słowo ideo, co jest niezwykle rzadkie. Taki zwrot (ideo in Christo) nie pojawia się w ówczesnych dokumentach papieskich czy cesarskich. Ponieważ jednak 
dwukrotnie posłużył się nim św. Augustyn ${ }^{3}$ który cieszył się w średniowieczu szczególnym zainteresowaniem i z którego chętnie czerpali ówcześni pisarze, uważałem i nadal uważam, że słowa takie mogły pojawić się w dokumencie w każdej epoce, zarówno w X, jak i w XII czy XIII w.

Inną kwestią jest hiperkrytycyzm D. Sikorskiego w stosunku do ustaleń moich czy innych badaczy, przy równoczesnej skłonności do wysuwania nieweryfikowalnych hipotez. Przytoczyć tu można jedną z nich: „Przecież zarówno Innocentemu II, jak i biskupom podpisanym potem na widymusie mógł ktoś przedstawić fałszerstwo naśladujące oryginalny dyplom papieski” (s. 33). Podobnie D. Sikorski pisze, polemizując z K. Uhlirzem, że nie można wykluczyć, by oryginalny dokument hersfeldzki został wykorzystany „np. w klasztorze w Hersfeld przez fałszerza pracującego na rzecz biskupstwa w Miśni”. Nie da się tego zweryfikować. Krytycyzm wobec innych i znaczną tolerancję wobec siebie samego możemy zaobserwować także w przypadku analizy zwrotu ne quis mortalium, którym posłużono się w dokumencie miśnieńskim zamiast słów ne qua parva magnave persona w bulli hersfeldzkiej. Przyjrzyjmy się bliżej tej kwestii. Otóż H. Zimmermann uznał zwrot ne quis mortalium za zgodny (pod względem sensu, ale nie dosłownie) z formularzem innych dokumentów tego czasu, co unaocznił przez wydrukowanie go petitem, a ostatnich dwóch słów tego zwrotu - petitem rozstrzelonym ${ }^{4}$. Mogłem właściwie wobec tego pominąc tę kwestię, słowa te bowiem rzeczywiście znaczą dokładnie to samo, co formularzowe ne qua parva magnave persona. Zwrotem ze słowem persona posłużył się także redaktor bulli miśnieńskiej dwukrotnie, pierwszy raz w nieco rozbudowanej formie w dyspozycji, a drugi raz powtarzając tekst dokumentu hersfeldzkiego ${ }^{5}$. Mimo spostrzeżeń H. Zimmermanna uznałem, że nie można przejść do porządku dziennego nad wyrażeniem ne qui mortalium, gdyż zwrot ten zgadzał się z passusem z Kodeksu Teodozjusza, powtórzonym w Kodeksie Justyniana. Trudno było to uznać za przypadek, gdy trzy kolejne słowa w prawniczym cytacie są całkowicie zgodne. Konieczne było rozwiązanie kwestii, czy w X w. w Rzymie któryś ze wspomnianych kodeksów mógł być znany. Dzięki pomocy jednego z polskich bizantynistów ustaliłem, że sprawę dawno rozwiązał Theodor Mommsen, a jego ustalenia zostały potwierdzone w 1953 r. przez największego wówczas znawcę tych zagadnień - Leopolda Wengera. Stosowną dokumentację zawiera przyp. $60 \mathrm{w}$ moim artykule. D. Sikorski te ustalenia podsumował jednym zdaniem: „Sądzi [Wojciech Jasiński], że prawo rzymskie mogło być znane w Italii”. Tak rzeczywiście sądzę, ale na podstawie ustaleń Mommsena i Wengera. D. Sikorski zgadza się wprawdzie, że rozważany zwrot bulli miśnieńskiej pochodzi z późnoantycznych kodeksów, ale uznaje jednak, że „sam w sobie nie jest wystarczająco charakterystyczny. Ponadto kontekst prawny nie nawiązuje do sytuacji z dokumentu miśnieńskiego czy jakiegokolwiek innego, w którym się

${ }^{3}$ Augustinus, Opus imperfectum contra Julianum, 6, 31: Ideo quippe in Adam omnes moriuntur, quia per hominem mors: sicut ideo in Christo vivificantur; tenże, De fide et operibus liber unus, 15 (25): atque ideo in Christo.

${ }^{4}$ Papsturkunden, t. I, s. VIII: „Gemäß den Regeln der Editionstechnik werden wörtliche Übereinstimmungen petit gesetzt, sinngemäße Übernahme petit gesperrt”.

5 Tamże, $\mathrm{nr} \dagger$ 187: nulla etiam magna vel parva alterius ordinis et gradus persona - -; alicui magne parveque persone. 
słowa te pojawiają (np. falsyfikat rzekomo wystawiony przez Ottona I w 900 r.: MGH DD O I, nr 435)". Oczywiście można przyjąć, że trzy identyczne słowa, w tym dwa ostatnie podlegające odmianie, w identycznej kolejności, to zbyt mało, skoro ponoć padają w innym kontekście. Jak dalece ma jednak ów kontekst nawiązywać? Oczywiście kwestie prawne związane z powstaniem biskupstwa miśnieńskiego nie mogły mieć swoich odpowiedników w Kodeksie Teodozjusza. Ale pewna paralelność tych rozporządzeń jest widoczna. W Kodeksie mowa wszak o tym, ,aby nikt z ludzi (śmiertelników) do tego stopnia nie popadł w zuchwałość w składaniu ofiary"6, a w dokumencie miśnieńskim zabrania się, ,aby nikt z ludzi (śmiertelników) nie uznał, że wolno mu [zająć siłą] cokolwiek z posiadłości Kościoła miśnieńskiego"?. Kontekst jest zatem podobny.

Nieco dalej D. Sikorski zauważa (s. 43), że ,w dokumentach z X i XI w. słowo mortalis pojawia się wprawdzie nie w tym samym zwrocie co w DM, ale w tej samej funkcji znaczeniowej (np. nulli mortalium)". Gdy ja wskazywałem zgodność trzech identycznych słów, nie był to dla D. Sikorskiego zwrot ,wystarczająco charakterystyczny"; gdy sam znajduje on powtarzające się pojedyncze słowo, wszelkie zastrzeżenia znikają. Od recenzowanego wymaga się więc spełniania innych standardów niż od samego recenzenta. Na marginesie należy zaznaczyć, iż rozważanego zwrotu nie znajdujemy bynajmniej w zacytowanym tu przez D. Sikorskiego dokumencie MGH DD O III, nr 26, który zresztą nie został wystawiony w 985 r., lecz 7 V 986 r. D. Sikorski miał zapewne na myśli inny dokument Ottona III z 4 I 992 r. (nr 79b), w którym zwrot ów znajduje się w części uznanej przez wydawcę za późniejszą interpolację (ut patrem et dominum nulli mortalium, nisi Romano pape et nobis tuicionis causa subiectum). Zgodność tylko jednego słowa z tego zwrotu z naszym dokumentem miśnieńskim prowadzi D. Sikorskiego do postawienia pytania: „Dlaczego zatem formularzowy zwrot ne qua parva magnave persona zastąpiono ne quis mortalium? Zauważmy, że owi mortales pojawiają się w DM w ustępach wzorowanych - o czym niżej - na dokumentach cesarskich MGH DD O II, nr 184 (z 983 r.) oraz O III, nr 186 (z 995 r.)". Przerywam w tym miejscu referowanie rozumowania D. Sikorskiego, gdyż - jak przekonamy się niżej, w trzeciej części tej wypowiedzi - wymienione dokumenty cesarskie przejęły ten zwrot właśnie z przywileju miśnieńskiego.

D. Sikorski (s. 41, przyp. 37) kwestionuje moje uwagi na temat kopii watykańskiej, w której miejsca pierwotnie nieodczytane wskazują, że jej twórca korzystać musiał z uszkodzonego na prawym marginesie egzemplarza, innego niż zachowany w dobrym stanie i świetnie czytelny oryginał widymusu z archiwum drezdeńskiego. D. Sikorski wskazuje, że „niewyjaśnione pozostają miejsca, które pierwszy kopista pozostawił puste w innych częściach tekstu". Nie dostrzegł widocznie, że przy zniszczeniu marginesu mogły ucierpieć także inne fragmenty dokumentu. Nie musiało tu przecież wcale wchodzić w grę obcięcie marginesu, jakie sugeruje D. Sikorski. Spiera

${ }^{6}$ Theodosiani libri XVI cum constitutionibus Sirmondianis et leges novellae ad Theodosianum pertinentes, wyd. Th. Mommsen, P. Meyer, Berlin 1905, t. I, cz. 2, s. 899 (16, 10, 9): Ne quis mortalium ita faciendi sacrificii sumat audaciam.

${ }_{7}$ Papsturkunden, t. I, $\mathrm{nr} \uparrow 187$ : interminamus, ne quis mortalium sibi licere existimet aliquid ex possessionibus Misnensis ecclesie [involare]; ostatnie słowo opuszczone i tu zrekonstruowane na podstawie dokumentu hersfeldzkiego. 
się on z poglądem, który sam wyimaginował, co sprowadza dyskusję na manowce. Nie można też zgodzić się z sugestią, że uzupełnienia opuszczonych pierwotnie miejsc mogły zostać naniesione w oparciu o tę samą podstawę, której nie umiał odczytać pierwszy kopista. Kardynał Garampi (z którego zbioru pochodzi rozważana kopia) i jego kopiści byli ludźmi niezwykle doświadczonymi, mistrzami paleografii - nie do pomyślenia wydaje się, że któryś z nich nie umiał odcyfrować tekstu, który w całości odczytał inny. Po cóż zresztą taki wysiłek, skoro miano już wtedy do dyspozycji co najmniej 6 edycji naszego dokumentu, które ci erudyci musieli znać, przystępując do kopiowania dokumentów dotyczących biskupstwa miśnieńskiego ${ }^{8}$. Wiemy zresztą, że sam Garampi bardzo interesował się manuskryptami przechowywanymi w Dreźnie, o czym możemy przeczytać w zachowanym jego opisie podróży z Warszawy do Drezna w 1776 r. ${ }^{9}$

Pomijam dalsze przykłady przeinaczeń, m.in. w kwestiach: (1) zbieżności przywilejów hersfeldzkiego i miśnieńskiego; (2) przypisania mi wszystkich poglądów Hutha; (3) oceny dokumentu papieskiego z 1131 r.; (4) przypisania mi poglądu, jakoby lepsze (w stosunku do hersfeldzkiego) lekcje dokumentu miśnieńskiego pochodziły z Liber diurnus; (5) twierdzenia, jakoby w drugiej połowie X w. znajomość Pseudo-Izydora w kancelarii papieskiej ograniczała się wyłącznie do notariusza Stefana; (6) przypisania mi twierdzenia, jakoby „wszystkie widoczne w DM różnice wobec DH znajdują potwierdzenie w zwyczajach kancelarii Jana XIII”.

II.

Publikując w 2013 r. mój artykuł o dokumencie miśnieńskim, przytoczyłem szereg argumentów przemawiających za jego autentycznością. Najważniejszy był ten, że gdyby dokument nasz był dziełem fałszerza z połowy XIII czy (jak uważa teraz D. Sikorski) z pierwszej połowy XII w., to jest niezwykle mało prawdopodobne, aby (1) fałszerzowi temu udało się dokonać przeredagowań tekstu zaczerpniętego $\mathrm{z}$ niewątpliwie autentycznego dokumentu hersfeldzkiego tak, że nie są one sprzeczne z wymogami formularza dokumentów Jana XIII, (2) dyspozycja odwoływała się do Pseudo-Izydora, którym chętnie posługiwał się wymieniony w dokumencie skriniariusz Stefan, a (3) redaktor w równym stopniu psuł rytmikę, jak czynił to notariusz układający dokument hersfeldzki.

Przyjrzyjmy się w skrócie tym trzem kwestiom. (1) Zauważyłem wcześniej, że gdy w kancelarii papieskiej redagowano dwa lub więcej zbliżonych do siebie dokumentów, sporządzonych nawet przez tego samego notariusza, to w formularzu tych dokumentów zawsze możemy zaobserwować drobne, mało istotne różnice. Te warianty w dużej części, ale nie wszystkie, pojawiają się już we wcześniejszych dokumentach danego papieża lub jego poprzedników. Przyjąłem też, że jeżeli w bulli miśnieńskiej znajdziemy takie drobne odstępstwa od formularza hersfeldzkiego, to powinniśmy sprawdzić, czy występowały one wcześniej w dokumentach Jana XIII

${ }^{8}$ Starsze edycje zestawione tamże.

${ }_{9}$ J. Ph. D e n g e 1, Nuntius Josef Garampi in Preussisch Schlesien und in Sachsen im Jahre 1776. Bericht über seine Reise von Warschau über Breslau nach Dresden, Quellen und Forschungen aus italienischen Archiven und Bibliotheken 5, 1903, s. 223-268. 
i jego najbliższych poprzedników. Jeżeli takie odstępstwa znajdziemy, to można przyjąć $\mathrm{z}$ dużą dozą prawdopodobieństwa, iż były one dziełem notariuszy papieskich z czasów Jana XIII, a nie fałszerza z XII lub XIII w. Fałszerz starałby się, po pierwsze, unikać wszelkich zmian, po drugie - nie mógł mieć wiedzy o wariantach w dokumentach Jana XIII i jego poprzedników, po trzecie zaś - jest niezwykle mało prawdopodobne, że wprowadzając drobne zmiany formularzowe, trafiłby akurat w takie odmianki, które znane były w kancelarii Jana XIII. Znalazłem dwie lub trzy takie odmianki: concessimus zamiast consciscimus, dodane ullo modo oraz bardziej poprawna sankcja w dokumencie miśnieńskim niż hersfeldzkim. Nadal uważam, że jest niezwykle małe prawdopodobieństwo, aby jakikolwiek fałszerz trafił w owe trzy warianty znane kancelarii Jana XIII lub jej bliskie. D. Sikorski starał się różnymi metodami umniejszyć wagę tych ustaleń. Pierwszym jego argumentem było stwierdzenie, iż odmianki te albo nie mają „,cech pozwalających powiązać je wyłącznie z kancelarią papieską i do tego konkretnie z czasami Jana XIII", albo są (jak zwrot nullo modo) ponadczasowe. Oczywiście łatwo byłoby prowadzić badania i dowodzić swoich racji, gdyby dokumenty każdego kolejnego papieża miał odrębny formularz i odmienne zwroty. To oczywiste, iż tak nie było i podnoszenie tej oczywistości jest nieporozumieniem. Istotna jest zupełnie inna kwestia, którą wyraźnie w moim artykule zaznaczyłem. Czy bardziej prawdopodobne jest to, że te trzy odmianki, zgodne $\mathrm{z}$ formularzem stosowanym za Jana XIII, zostały wprowadzone przez jego notariusza, czy to, że też dzięki ślepemu losowi utrafił w nie późniejszy fałszerz. W ogóle zresztą to raczej notariusze Jana XIII, dobrze znający kancelarię papieską, zdecydować się mogli na wprowadzenie drobnych odmianek. Fałszerz bałby się manipulować przy wykorzystanej podstawie, a zwłaszcza odstąpić od niezwykle rzadkiego, właściwie w ogóle niespotykanego, słowa consciscimus.

(2) Muszę przyznać, że sprawa posługiwania się Pseudo-Izydorem w kancelarii papieskiej od końca IX w. aż do czasów skriniariusza Stefana jest trochę bardziej skomplikowana, niż przyjmowałem to w moim artykule na podstawie badań H. Fuhrmanna. Nadal podzielam jego pogląd, iż Decretales Pseudo-Izydora odgrywały ważną rolę w dokumentach papieskich redagowanych przez skriniariusza Stefana. Uważam, że twierdzenia D. Sikorskiego w tej sprawie należy odrzucić jako nielogiczne i błędne, co niżej będę starał się dowieść na podstawie analizy dokumentów zredagowanych przez skriniariusza Stefana. Zanim jednak do tego przejdziemy, przypomnijmy najpierw dotychczasowe ustalenia. Otóż zgodnie z ustaleniami H. Fuhrmanna, od końca IX w., dokładnie od 899 r., aż po czasy skriniariusza Stefana za pontyfikatu Jana XIII nikt nie posługiwał się Decretales. Podzielając ten pogląd, nie dysponowałem wówczas przeszukiwalną wersją edycji dokumentów papieskich H. Zimmermanna. Dopiero po opublikowaniu mojego artykułu udostępnił mi ją D. Sikorski, za co jestem mu bardzo wdzięczny. Dzięki wykorzystaniu tego narzędzia można wskazać, że H. Fuhrmann przeoczył przynajmniej jedno nawiązanie do Decretales w X w., w okresie poprzedzającym powstanie dokumentów zredagowanych przez wzmiankowanego Stefana. H. Zimmermann, a za nim D. Sikorski, odnotowali cytaty $\mathrm{z}$ Decretales $\mathrm{w}$ dwóch dokumentach, ale tak naprawdę mamy do czynienia $\mathrm{z}$ jednym ewidentnym cytatem w dokumencie Marinusa II dla biskupa Kapui z 943/944 r. 
Drugie nawiązanie jest zbyt ogólne, aby mieć pewność, że pochodzi z Pseudo-Izydora ${ }^{10}$. Nie możemy zatem mówić za H. Fuhrmannem, że Pseudo-Izydor wyszedł całkowicie z użycia w kancelarii papieskiej od 899 r. aż po czasy skriniariusza Stefana, ale że posługiwano się nim całkowicie sporadycznie, z pewnością raz, a może dwa razy.

Stefan niewątpliwie jako pierwszy skriniariusz $\mathrm{X}$ w. zaczął często w redagowanych przez siebie dokumentach odwoływać się do Pseudo-Izydora. Jego rolę w tym zakresie stara się różnymi sposobami - moim zdaniem zupełnie niesłusznie - pomniejszyć D. Sikorski. Pisze on m.in. (s. 39): „Dowody na znajomość Pseudo-Izydora przez notariusza Stefana, który sporządził DH i miałby być autorem DM, szczególnie uwypuklone przez Horsta Fuhrmanna, są w rzeczywistości o wiele bardziej ograniczone, niż sądził niemiecki historyk, a za nim Autor. W sporządzonym przez Stefana dokumencie erekcyjnym metropolii magdeburskiej z 967 r. (PU [Papsturkunden] nr 177) można jedynie mówić o wpływie pseudoizydoriańskich wyobrażeń o strukturze Kościoła (według rzekomego listu papieża Klemensa I)”. Ostatnie zdanie jawi się jako ważna odautorska korekta ustaleń Fuhrmanna, ale tak naprawdę jest powtórzeniem stwierdzenia tego badacza, które cytowałem zresztą w moim artykule (s. 23-24: „H. Fuhrmann zauważa jednak, że już słynny przywilej dla Magdeburga z synodu w Rawennie z 967 r. zdradza pokrewieństwo z Decretales Pseudo-Isidorianae, a zwłaszcza z wymienionym listem papieża Klemensa, choć nie jest jego dosłownym cytatem"). Nie wnoszą nic nowego dalsze uwagi D. Sikorskiego o dokumencie Jana XIII z 22 I 969 r. dla arcybiskupstwa trewirskiego, gdyż są powszechnie znane od czasu edycji Zimmermanna. Najistotniejsza jest jednak uwaga, iż „te nawiązania do Pseudo-Izydora w dyplomatyce papieskiej, które możemy uznać za pewne, pochodzą wprawdzie z dokumentów zredagowanych przez Stefana, ale oddają one postanowienia synodów. W takim razie trudno uznać, że wprowadził je wyłącznie kancelista Stefan. Teksty tych dokumentów oddają raczej argumentację obecnych na synodach biskupów". Trudno wyobrazić sobie, jak miałoby to wyglądać w praktyce. Ponieważ często mamy do czynienia z cytatami, musiałby taki biskup specjalnie przywozić na synody Decretales Pseudo-Izydora. Ba, musiałoby być więcej takich biskupów czy arcybiskupów, gdyż do Decretales odwoływano się kilkakrotnie na przestrzeni kilkunastu lat, a uczestnicy synodów ciągle się zmieniali. Mało tego, taki uczestnik czy uczestnicy synodu musieliby za każdym razem ingerować w pracę kancelarii papieskiej i skłaniać Stefana lub jego pomocników do wpisywania do dokumentów papieskich wskazanych cytatów. Oczywiście jest to zupełnie nieprawdopodobne. To, że cytaty z Pseudo-Izydora występują dość często w dokumentach wystawionych w czasie obrad synodów, można wytłumaczyć tym, iż na synodach nierzadko rozpatrywane były skomplikowane czy nietypowe sprawy, które wymagały nietypowych argumentów, a te można było znaleźć przede wszystkim w Pseudo-Izydorze.

To, że D. Sikorski się myli w tej kwestii, dowodzi fakt zachowania się dokumentu zredagowanego przez Stefana z wtrąceniami z Pseudo-Izydora, który nie został wystawiony w czasie synodu, a który przeoczyli H. Fuhrmann i H. Zimmermann. Chodzi o dokument Jana XIII z kwietnia 972 r. dla biskupa Piotra z Pawii ${ }^{11}$.

\footnotetext{
${ }_{10}$ Papsturkunden, t. I, nr 100, 137.

11 Tamże, nr 220.
} 
Dla dużych fragmentów jego arengi H. Zimmermann nie mógł znaleźć paraleli, który to fakt odnotował przez wydrukowanie 17 wyrazów powiększonym drukiem (co w poniższym porównaniu zastąpiono podkreśleniem). Wydawca ten nie wiedział, że arengę tę, w pierwszej części nieco zmienioną, a w drugiej w identycznym brzmieniu, odnajdujemy w Pseudo-Izydorze, w rzekomych dekretach Fabiana ${ }^{12}$. Zbieżności (zaznaczone pogrubioną czcionką) pokazuje zestawienie:

\begin{tabular}{|c|c|}
\hline Dokument Jana XIII, nr 220 & Pseudo-Izydor, Fabiani decreta \\
\hline $\begin{array}{l}\text { cura est sollicitudinis adhibenda, ut ea, quę } \\
\text { pro quiete religiose congregationis fuerint } \\
\text { ordinata, nec dissimulatio neglegere, nec } \\
\text { quedam valeat presumptio perturbare, } \\
\text { sed sicut hoc, quod rationis exigit utilitas, } \\
\text { oportet definiri, ita quod definitum fuerit, } \\
\text { non debet violari. }\end{array}$ & $\begin{array}{l}\text { cura est ergo vestrae sollicitudinis adhibenda, } \\
\text { ut ea, quae sunt ab apostolis eorumque } \\
\text { successoribus ordinata, et instigante sancto } \\
\text { spiritu instituta, nec dissimulatio neglegere, } \\
\text { nec aliqua praesumptio valeat perturbare, } \\
\text { sed sicut hoc quod rationis exigebat utilitas } \\
\text { oportuit definire, ita quod definitum est non } \\
\text { debet violari. }\end{array}$ \\
\hline
\end{tabular}

Nawet zresztą gdyby teza D. Sikorskiego o wpływie uczestników synodów była prawdziwa, a niestety nie jest, to wzmacniałoby to tylko moją argumentację na rzecz autentyczności bulli miśnieńskiej z 968 r. Okazywałoby się bowiem, że krąg dokumentów, w których w tym czasie posługiwano się Pseudo-Izydorem, był jeszcze węższy, niż dowodził tego H. Fuhrmann. Byłyby to tylko dokumenty zredagowane przez Stefana, i to wyłącznie w czasie synodów. $Z$ tej perspektywy dokument miśnieński jawi się jako niezwykle wiarygodny, gdyż był on zredagowany przez Stefana i to właśnie w czasie synodu.

Dariusz Sikorski dowodzi, że już w X w. posługiwano się Decretales jako pomocą przy sporządzaniu falsyfikatów dokumentów papieskich; przekonująco pokazuje, że znajomość Pseudo-Izydora przypada na XII w. i że wiele średniowiecznych kolekcji rękopiśmiennych przejęło Decretales, które nie były zatem tak rzadkie, jak można by przypuszczać. To wszystko prawda, ale posłużenie się Decretales przy redagowaniu dokumentu miśnieńskiego przez fałszerza ok. 1130 lub ok. 1250 r. jest wyjątkowo mało prawdopodobne. Musielibyśmy mieć do czynienia jednocześnie z dwoma mało prawdopodobnymi zrządzeniami losu. Domniemany fałszerz musiałby najpierw przypadkiem znaleźć w archiwum klasztornym w Hersfeld bullę zredagowaną przez Stefana lub ewentualnie pozyskać - czego nie wyklucza D. Sikorski - wewnątrz tego klasztoru fałszerza, który pracowałby dla biskupstwa miśnieńskiego; fałszerz, nie wiedząc o tym, że skriniariusz Stefan miał predylekcję do Pseudo-Izydora, musiałby w dodatku dobrać przypadkiem tekst z Decretales.

(3) Analiza rytmiki bulli hersfeldzkiej i miśnieńskiej dowiodła, że spisane zostały one przez osobę lub osoby, które nie miały pojęcia o cursusie. Skriniariusz Stefan w takim samym stopniu psuł rytmikę Liber diurnus, jak redaktor bulli miśnieńskiej psuł ocalałe rytmy z bulli hersfeldzkiej. Uważam, że w XII i XIII w. cursus był już na tyle znany poza kancelarią papieską, że fałszerz nie zepsułby rytmów z bulli

${ }_{12}$ Decretales Pseudo-Isidorianae et capitula Angilramni, wyd. P. Hinschius, Lipsiae 1863, s. 160 . 
hersfeldzkiej; bez Liber diurnus nie mógłby w dodatku wiedzieć, że niektóre rytmy już w tej ostatniej zostały popsute.

III.

Kluczowym dla D. Sikorskiego argumentem mającym dowodzić nieautentyczności przywileju Jana XIII dla Miśni jest rzekoma zależność tej bulli od dwóch dokumentów cesarskich: Ottona II z 27 II 983 r. (MGH DD O II, nr 184) oraz Ottona III z 995 r. (MGH DD O III, nr 186). Zagadnienie to jest niezwykle skomplikowane i można je dwojako interpretować, jako zależność tych dokumentów od bulli miśnieńskiej lub też odwrotnie - tak jak uważa D. Sikorski - jako zależność tejże bulli od tych przywilejów. Przy analizie tych zależności D. Sikorski popełnił kilka zaskakujących błędów. Pisze, że w dokumencie Ottona III przywołany został jedynie Otto II, ,prawdopodobnie dlatego, że Otto III w części potwierdzał jego nadania (MGH DD O II, nr 184)" (s. 46). Na dowód tego, że dokument z 995 r. wymienienia tylko Ottona II, badacz przytacza w skróconej formie cytat z tego dokumentu: pro remedio animarum - - patris nostri. Przyjrzyjmy się jednak nieskróconemu fragmentowi, przytoczonemu zresztą 4 linijki dalej: pro remedio animarum dilecti avi nostri simul et patris nostri. Nie ulega wątpliwości, że ów avus noster to Otto I. Nie twierdzę, że D. Sikorski nie wie, że avus to „dziad”, ale znamienne, że przeoczył ten fakt dwukrotnie, najpierw wycinając owego dziada z cytatu mającego dowodzić, iż w dokumencie został wymieniony tylko Otto II, potem zaś - przytaczając pełen cytat.

D. Sikorski tak pisze o zależności bulli miśnieńskiej i przywilejów ottońskich: „Jeśli tekst z DM miałby być pierwotny, to trzeba by uznać, że w 983 r. wyciągnięto z niego tylko zaznaczone pogrubionym drukiem fragmenty, a w dyplomie z 995 r. - już całość” (s. 46). Wyjaśnijmy, że dokument miśnieński w części z opisem granic biskupstwa oraz dziesięcin jest niemal identyczny z dyplomem Ottona III (995), a ponadto ma kilka wspólnych zwrotów z dokumentem Ottona II (983). Przyjmijmy zatem jako eksperyment twierdzenie D. Sikorskiego, iż przywilej miśnieński jest falsyfikatem i powstał dopiero w pierwszej połowie XII w. Przyjrzyjmy się z tej perspektywy dokumentowi Ottona III z 995 r., który został zredagowany w kancelarii tego władcy przez notariusza oznaczanego syglą $\mathrm{HI}^{13}$. Na pierwszy rzut oka wydaje się, że dokument

${ }^{13}$ D. Sikorski wpierw postponuje ten dokument (s. 34), a następnie czyni go głównym dowodem nieautentyczności przywileju miśnieńskiego. Zbyt daleko idące jest stwierdzenie, że jest to falsyfikat (s. 44). Nasz adwersarz idzie tu za ustaleniami Th. Ludwiga, który pisze: „,nach den jüngsten Untersuchungen handelt es sich um ein unvollzogen gebliebenes Original, das keinerlei Gewähr dafür bietet, dass sein Inhalt dem Willen des als Aussteller genannten Königs entsprach”. Od dawna wiadomo jednak, że czystopis dokumentu został spisany przez cesarskiego notariusza, co potwierdziły nowsze badania i o czym wspomina też D. Sikorski. Trudno jednak sobie wyobrazić, żeby w kancelarii cesarskiej najpierw wygotowywano czystopisy, później dopiero proszono władcę o akceptację, a w razie jej odmowy wydawano odbiorcy czystopis bez pieczęci. Bardziej prawdopodobny jest pogląd, że dokumenty, które zlecano przygotować notariuszom, uzyskiwały wcześniej akceptację cesarską; nie chodziło tylko o zapobieżenie bezmyślnego marnowania pergaminu, ale przede wszystkim o bezpieczeństwo cesarskich interesów, gdyż wystawione bez zgody monarszej czystopisy mogły być wykorzystywane nawet nieopieczętowane. Zresztą fakt, że dzisiaj sposób przywieszenia 
ten opierał się na przywileju Ottona II z $983 \mathrm{r}$. Wspomniany przez D. Sikorskiego cytat wydaje się dowodzić, iż tak rzeczywiście było. Rzućmy okiem na zbieżności:

\begin{tabular}{|c|c|}
\hline Otto II (MGH DD O II, nr 184) & Otto III (MGH DD O III, nr 186) \\
\hline $\begin{array}{l}\text { In nomine sanctae et individuae trinitatis. } \\
\text { Otto divina favente clementia imperator } \\
\text { augustus. - - } \\
\text { tradidimus quandam villam Setleboresdorf } \\
\text { vocitatam iacentem in burcwardo Boruz dicto } \\
\text { prope fluvium qui Albia dicitur, Misnensi } \\
\text { ecclesiae cui venerabilis Folcholdus episcopus } \\
\text { praeesse dinoscitur, cum omnibus rebus iuris } \\
\text { nostri in eodem villae situ manentibus et } \\
\text { accidentibus, proventus in theloneo quod ad } \\
\text { fiscum nostrum pertinuerat, a civitate quae } \\
\text { dicitur Belegora usque ad eiusdem Misnensis } \\
\text { ecclesiae portum sursum indeque denuo } \\
\text { per ambas plagas praefati fluminis Albiae } \\
\text { deorsum sicque infra praefinitum terminum, } \\
\text { ubicumque manus negociatorum ultra Albiam } \\
\text { huc illucque sese diverterit, ex integro et } \\
\text { absque ulla contradictione theloneum eidem } \\
\text { praenominatae Misnensi sedi persolvant, } \\
\text { veluti ad fiscum nostrum debuerint. Igitur } \\
\text { post haec statuimus ut omnes qui in eodem } \\
\text { burgwardo habitent, omnem decimacionem } \\
\text { rerum suarum, scilicet frugum pecudum } \\
\text { pecuniarum vestimentorum mellis et } \\
\text { crusinarum nec non quod Theutonici dicunt } \\
\text { uvarcophunga et talunga familiarum et } \\
\text { omnium utilitatum quibus mortales utuntur, } \\
\text { in eandem Misnensem civitatem deo sanctoque } \\
\text { Iohanni ewangelistae et sancto Donato martiri, } \\
\text { omni ambiguitate procul remota, persolvant } \\
\text { referant et reddant. }\end{array}$ & $\begin{array}{l}\text { In nomine sanctae et individuae trinitatis. } \\
\text { Otto divina favente clementia rex. -- } \\
\text { Misnensi episcopatui terminum posuimus } \\
\text { nominando fines et determinationes locorum } \\
\text { sicut infra tenetur: ubi caput et fons aquae } \\
\text { quae dicitur Odera, inde quasi recta via usque } \\
\text { ad caput Albiae; inde deorsum in occidentalem } \\
\text { partem ubi divisio et confinium duarum } \\
\text { regionum Behim et Nisenin, ibidem ultra } \\
\text { Albiam et per silvam in occidentalem partem } \\
\text { usque ad caput Mildae et sic deorsum ambas } \\
\text { plagas eiusdem fluminis, scilicet prope } \\
\text { occidentalem ripam Rochilinze, et sic usque } \\
\text { dum Milta intrat in Albiam, nec non ob hoc } \\
\text { diximus in occidentali plaga quia multae villae } \\
\text { pertinent ad orientales urbes, et sic sursum et } \\
\text { ultra provinciam Nizizi ad eundem terminum } \\
\text { sine dubio, nec non in altera parte Lusizi } \\
\text { et Selboli et sic usque ad civitatem Zulbiza, } \\
\text { illam videlicet infra eundem terminum, et } \\
\text { inde in aquam quae dicitur Odera et sic Odera } \\
\text { sursum usque ad caput eius. Omnes vero } \\
\text { qui infra terminum istum habitent, in omni } \\
\text { fertilitate terrae frugum et pecudum, in } \\
\text { argento vestimento nec non quod Teutonici } \\
\text { dicunt ovarcapunga et talunga familiarum, } \\
\text { insuper tota utilitate et in omnibus rebus } \\
\text { quibus mortales utuntur diversis modis, } \\
\text { decimationes quas deo cuncta gubernanti } \\
\text { debent, ad Misnensem aecclesiam primo deo, } \\
\text { deinde sancto Iohanni evangelistae beatoque } \\
\text { Donato martyri dei, universa dubietate procul } \\
\text { remota, persolvant referant et reddant. }\end{array}$ \\
\hline
\end{tabular}

Przypomina się zastrzeżenie D. Sikorskiego wobec dokumentu miśnieńskiego. Można je mutatis mutandis powtórzyć: Jeśli dokument Ottona II miałby być pierwotny w stosunku do przywileju Ottona III, to zaskakuje, iż wyciągnięto z niego tylko zaznaczone pogrubieniem fragmenty. Teoretycznie można wytłumaczyć to różnicami w zakresie odnośnych nadań. W przywileju z $983 \mathrm{r}$. cesarz nadał wieś Setleboresdorf w okręgu grodowym Boritz, cło na Łabie od Białej Góry (Belgern) aż po Miśnię oraz dziesięciny z tegoż okręgu grodowego. Natomiast dokument Ottona III określa

pieczęci przy tym dokumencie nie jest oryginalny, nie dowodzi, iż tak musiało być w XII w. Zauważmy wreszcie, że Th. Ludwig wszelkie niemal wątpliwości odnośnie do autentyczności interpretuje jako dowód fałszerstwa. Takie hiperkrytyczne stanowisko, jak dowodzą choćby dzieje polskiej dyplomatyki, w której podobną postawę okazywał kiedyś Wojciech Kętrzyński, nie zawsze musi przybliżać do prawdy. 
granice biskupstwa i nadaje mu dziesięciny. Pojawienie się wspólnego zwrotu (per) ambas plagas fluminis, czyli „po obu brzegach rzeki” może być i najpewniej jest przypadkowe, natomiast za takie nie można uznać wspólnych zwrotów opisujących sposób płacenia dziesięciny. Pisarz HI musiałby przepisać dosłownie z dokumentu Ottona II tylko te fragmenty, które są w nim wspólne $\mathrm{z}$ dokumentem miśnieńskim. Tę zadziwiającą zależność da się wyjaśnić, gdy całkowicie odwrócimy nasze rozumowanie i bliżej przyjrzymy się wzajemnemu stosunkowi dokumentów Ottona II i Ottona III. Chociaż część słów w nich jest taka sama lub równoznaczna, to jednak uważna ich lektura nie pozostawia wątpliwości, że dokument Ottona II nie mógł być podstawą przy redagowaniu przywileju Ottona III. Odnośny fragment dokumentu Ottona II jest zredagowany prosto i czytelnie: w obrębie okręgu grodowego mieszkańcy mają płacić dziesięcinę z wymienionych dóbr. Jakkolwiek w dokumencie Ottona III wiele elementów paralelnego tekstu zostało napisanych podobnie, to jednak sprawa dziesięcin została tu opisana pod względem stylistycznym niezwykle skomplikowanie. Gdy u Ottona II dobra, od których miano pobierać dziesięciny, zostały wyliczone na jednym poziomie gramatycznym, jako przydawki dopełnienia, to w dokumencie Ottona III zostały wymienione jako dopełnienia przedmiotowe dalsze z różnymi konstrukcjami ${ }^{14}$. Przyjrzyjmy się bliżej temu zdaniu $\mathrm{w}$ dokumencie Ottona III: po podmiocie ${ }^{15}$, następuje sześć dopełnień przedmiotowych dalszych, które wraz z dwoma zdaniami podrzędnymi, poprzedzają dopełnienie bliższe. Nim czytelnik dobrnie do dopełnienia bliższego (decimationes), przez cały czas nie wie, do czego odnieść owe dopełnienia przedmiotowe dalsze. Pierwsze z owych dopełnień przedmiotowych dalszych zostało ponadto sformułowane w sposób dezorientujący. Mianowicie konstrukcja przyimkowa tego dopełnienia z in (in omni fertilitate) uzupełniona została trzema przydawkami w genetiwie (terrae, frugum et pecudum). Taka konstrukcja dopełnienia dalszego powoduje, że dobra, od których płacono dziesięciny, nie były wymienione w dokumencie Ottona III na jednym poziomie gramatycznym. Po trzeciej przydawce następuje drugie dopełnienie przedmiotowe dalsze z konstrukcją przyimkową z in, a po niej kolejne $\mathrm{z}$ domyślną konstrukcją przyimkową $\mathrm{z}$ in Zaskakuje przy tym, iż w trzecim dopełnieniu dalszym pisarz, naśladując drugie dopełnienie dalsze, nadał nieułomnemu rzeczownikowi status rzeczownika singularia tantum (vestimento). Po nim następuje czwarte dopełnienie dalsze domyślne („w tym”), które opisane zostało w formie zdania podrzędnego: quod Teutonici dicunt $^{16}$. Później mamy dwa dalsze dopełnienia przedmiotowe $\mathrm{z}$ dwiema różnymi konstrukcjami przyimkowymi: insuper oraz in. Nie na tym koniec komplikacji, gdy bowiem czytelnik dochodzi wreszcie do dopełnienia bliższego (decimationes) i już zaczyna mieć nadzieję, że teraz dowie się, co stanie się z owymi dziesięcinami, zaskoczony zostaje truizmem: quas cuncta deo gubernanti debent. Dopiero po tym zdaniu podrzędnym czytelnik dowiaduje się, komu zostały przyznane dziesięciny, po określeniu którego i dodaniu informacji o konieczności pozbycia się wątpliwości,

${ }^{14}$ Dziękuję w tym miejscu uprzejmie Panu Prof. Stanisławowi Mikołajczakowi za konsultacje w zakresie terminologii językoznawczej.

${ }_{15}$ Pomijam tu zdanie podrzędne, które następuje po podmiocie i które go definiuje, gdyż analogiczne zdanie spotykamy w dokumencie Ottona II.

${ }_{16}$ Paralelne zdanie spotykamy w dokumencie Ottona II. 
całe zdanie (główne), zgodnie z właściwością języka łacińskiego, zamyka orzeczenie, dopełnione szeregowo dwoma innymi ${ }^{17}$.

Żaden notariusz cesarski, a w tym również notariusz HI, mając przed oczyma prosty i czytelny tekst przywileju Ottona II, nigdy nie skonstruowałby na jego podstawie tak zawiłego zdania, w którym liczne dopełnienia dalsze poprzedzały dopełnienie bliższe, a dodatkowe zdanie podrzędne, nic niewnoszące, dodatkowo komplikowało narrację. Można zresztą pokazać, że notariusz HI nie dokonywał niepotrzebnych zmian w wykorzystywanych tekstach. Otóż 23 XI 994 r. redagował dokument Ottona III (MGH DD O III, nr 156), zawierający jedno z nadań dla Kościoła mogunckiego, które wcześniej, w 977 r., potwierdził już Otto II (MGH DD O II, nr 150). Wiernie trzymał się pierwowzoru, zmieniając jedynie te elementy, które były konieczne w związku z nową redakcją, pozostałe zaś pozostawiał w zasadzie bez zmian. Gdyby jednak ktoś uznał, że wspomniana komplikacja jest niewystarczającym dowodem przemawiającym za tym, iż notariusz HI nie układał swojego tekstu na podstawie przywileju Ottona II, to możemy wskazać na dodatkowy dowód. Otóż, gdyby notariusz HI miał przed sobą dokument z 983 r., to z pewnością nie pominąłby dwóch ważnych dziesięcin, a mianowicie dziesięciny z miodu i skórek zwierzęcych, które były szczególnie ważne na terenach zamieszkałych przez Słowian. Jak ważna była to dziesięcina, dowodzi dokument Ottona I z 971 r., który nadał wówczas Kościołowi miśnieńskiemu dziesięciny z pięciu terytoriów plemiennych: in melle, crusina, solutione argenti, mancipiis, vestimentis, porcis, frumento, et ut in quirendis rebus, quod vulgo uberchoufunga vocatur. Gdyby jednak ktoś twierdził, iż w dokumencie Ottona III z 995 r. świadomie pominięto miód i skórki, gdyż Kościół miśnieński nie miał otrzymywać $\mathrm{z}$ nich dziesięcin, to powinno to zostać odnotowane $\mathrm{w}$ dokumencie, $\mathrm{np}$. zwrotem exceptis decimationibus mellis et crusinae, quas nobis reservamus itp.

Możemy zatem stwierdzić, iż notariusz HI, redagując dokument Ottona III z 995 r., nie opierał się na dokumencie Ottona II z 983 r. Mało tego, gdybyśmy się ograniczyli wyłącznie do porównania zapisów dotyczących dziesięcin, to odnieślibyśmy wrażenie, że to raczej tekst $\mathrm{z}$ dokumentu Ottona II powstał na skutek przeredagowania i uzupełnienia dokumentu Ottona III. Oczywiście to niemożliwe, aby starszy dokument został spisany na podstawie młodszego, ale zabieg przeredagowania w dokumencie Ottona II tekstu znanego z dokumentu Ottona III widoczny jest jak na dłoni. Autor dokumentu z 983 r. przesunął dopełnienie bliższe (omnem decimacionem) na początek zdania, zaraz po podmiocie ${ }^{18}$, usunął zbędny i wprowadzający zamieszanie zwrot in omni fertilitate, wszystkie dziesięciny wymienił jako przydawki dopełnienia bliższego, a nie jako dopełnienia dalsze z różnymi konstrukcjami przyimkowymi (in, in domyślne, insuper). Zmodernizował nawet terminologię w wypadku dziesięciny ze srebra na dziesięcinę z pieniędzy. Wprowadził właściwą liczbę (mnogą) w wypadku rzeczownika vestimentum, przez co pozbawił ten rzeczownik rzekomego statusu singularia tantum. Na koniec wreszcie uzupełnił spis dziesięcin o niezwykle ważne dziesięciny z miodu i skórek zwierzęcych. Przepisał bezbłędne zdanie nec non quod

${ }^{17}$ Te elementy zdania głównego mają swoje paralele w dokumencie Ottona II.

18 Pomijam - podobnie jak w wypadku dokumentu Ottona III - paralelne zdanie podrzędne, wyjaśniające, o jakich mieszkańców chodzi. 
Theutonici itd., usunął truizm quas cuncta deo gubernanti debent i dokonując tylko drobnych zmian stylistycznych, zaakceptował niebudzącą wątpliwości końcówkę zdania głównego.

Oczywiście redaktor dokumentu Ottona II z 983 r. - jak już wspomnieliśmy nie mógł przeredagowywać dokumentu z 995 r. Mógł mieć natomiast przed oczami dwa inne dokumenty: Jana XIII dla Miśni z 2 I 968 r., który uprościł pod względem stylistycznym, oraz dokument Ottona I z 971 r., z którego zaczerpnął wzmiankę o dwóch ważnych dziesięcinach. Bez wykorzystania bulli papieskiej z $968 \mathrm{r}$. nie sposób wyobrazić sobie powstania paralelnych zwrotów w dokumentach z 983 i 995 r. Ponadto, gdyby redaktor dokumentu Ottona II z 983 r. nie znał naszej bulli, to wówczas kolejność i nazwy dóbr, z których płacono dziesięciny, przejąłby najpewniej z dokumentu Ottona I z 971 r. A jednak opis ten zmienił, przestawiając kolejność i używając innej nomenklatury. Skłonić do tego mógł go tylko dokument papieski.

Ostatecznie nie da się wytłumaczyć zarówno zależności, jak i rozbieżności między dokumentami cesarskimi dla Miśni z lat 971, 983 i 995 bez istnienia przywileju papieskiego Jana XIII z 2 I 968 r. To właśnie ten dokument miał też przed sobą notariusz HI, gdy w 995 r. spisywał dokument Ottona III i przepisał go niemal dosłownie, bez przeredagowań i uproszczeń, które były dziełem notariusza dokumentu Ottona II z 983 r. Idźmy jednak dalej i spójrzmy na stosunek dokumentu Ottona III z 995 r. do dokumentu Jana XIII dla Miśni. Zwrot more antiquorum imperatorum hii duo imperatores, pater et filius, który od słowa hii znajdujemy tylko w dokumencie papieskim z 968 r., doskonale oddaje atmosferę towarzyszącą koronacji cesarskiej Ottona II, przeprowadzonej vivente imperatore, dokładnie na tydzień przed powstaniem bulli dla Miśni. Wyrażenie pater et filius jako określenie panujących na ziemi, można uznać za majstersztyk propagandy tamtych czasów, gdyż niewątpliwie wywoływało skojarzenie z Ojcem i Synem panującymi w niebiosach. Kim byli owi antiqui imperatores? Pojawiają się oni w jednym z dokumentów Ottona I, gdy otrzymał on już koronę cesarską (MGH DD O I, nr 241). Chodzi oczywiście o wcześniejszych władców z dynastii Karolingów, którzy też dostąpili tej godności. To wpisywanie się w dawną tradycję imperialną Karolingów widoczne jest zwłaszcza w momencie koronacji cesarskiej Ottona II 25 XII 967 r. W powstałych z tej okazji z inspiracji Wilhelma - arcybiskupa mogunckiego, brata przyrodniego i wychowawcy Ottona II - tekstach, jak Continuatio Reginonis, a zwłaszcza Roczniki mogunckie (których kopią jest Rocznik obcy zawarty w Roczniku kapituły krakowskiej), przedstawiano rządy Liudolfingów jako kontynuację dokonań Karolingów ${ }^{19}$. Gdyby natomiast Otto III chciał przywołać swoich dwóch bezpośrednich poprzedników, to jego notariusz zrobiłby to tak, jak napisał we wstępie tego dokumentu, a mianowicie pisałby wprost o ojcu i dziadzie, a ostatecznie mógłby napisać more antecessorum imperatorum nostrorum, avi et patris itp. Uderzanie w tony imperialnej tytulatury przez Ottona III, gdy był jeszcze tylko królem, podkreślałoby tylko jego podrzędną pozycję w stosunku do dziada i ojca. To, że imperialna tytulatura nie była w tym momencie na rękę Ottonowi III, świadczą słowa z jego dokumentu z 995 r., za pomocą

19 T. J a s i ń s k i, Zagadnienie autorstwa Rocznika obcego. Przyczynek do dziejów historiografii niemieckiej X stulecia, Roczniki Historyczne 68, 2002, s. 7-25, zwł. s. 16 n. 
których starał się dostosować te ,wysokie tony” do swej podrzędnej sytuacji: et regum nostra regali potestate. Gdyby rzeczywiście fałszerz z XII w. wspierał się na dokumencie Ottona III z 995 r., to możemy przypuszczać, że nie usunąłby tych słów (których brak w dokumencie miśnieńskim), lecz jako istotną część dokumentu zmienił np. na eorum imperiali potestate. To, że pomysłowość fałszerza powinna iść w takim kierunku, świadczy datowany na 948 r. rzekomy dokument Ottona I, sfałszowany ok. 1250 r., a opierający się na dokumencie Ottona III z 995 r.: et regum nostra imperiali potestate (MGH DD O I, nr 437). Widać, że fałszerz tu ,przedobrzył”, gdyż nie powinien posłużyć się zwrotem o władzy cesarskiej w odniesieniu do czasu, kiedy Otto nie był jeszcze cesarzem. Inny z kolei fałszerz (MGH DD O I, $\mathrm{nr} 449)$ zapomniał zmienić nostra regali potestate na nostra imperiali potestate, gdyż w momencie rzekomego roku wystawienia, w 968 r., Otto I był już cesarzem. Widać jak na dłoni, że fałszerze popełniali proste błędy, których nie znajdziemy w dokumencie miśnieńskim. Wątpliwe też, że fałszerz w pierwszej połowie XII w. wpadłby na pomysł, aby do tekstu wprowadzić słowa pater et filius czy też w dalszej części dokumentu dopisać: quemadmodum hii presentes imperatores statuisse fatentur. Oczywiście można wysuwać różne kontrargumenty, twierdzić, że bywali genialni fałszerze, jednak jednej rzeczy nie da się wyjaśnić. Otóż żaden z fałszerzy z XII czy XIII w. po wprowadzeniu zwrotu hii duo imperatores, pater et filius nie wpadłby na to, aby pamiętać, że należy dodać jeszcze słowa nobis [tj. papieżowi] assidentes. Jest natomiast zupełnie zrozumiałe, że pamiętał o tym notariusz czy skriniariusz papieski w 968 r. $^{20}$

Należy wreszcie omówić sprawę zapożyczenia przez rzekomego fałszerza tekstu z dokumentu Ottona II z 983 r. (MGH DD O II, nr 184). Określenie biskupa-odbiorcy jest w obu identyczne: Misnensis ecclesie, cui venerabilis episcopus Burcardus preesse dinoscitur (968) oraz Misnensi ecclesiae, cui venerabilis Folcholdus episcopus praeesse dinoscitur (983) Kwestia ta wymaga kilku wyjaśnień. Nieprawdą jest, że „formuła episcopus - - dinoscitur lub podobna nie pojawia się w dyplomatyce papieskiej przynajmniej do połowy XI w." (jak pisze D. Sikorski, przyp. 14). Formuła ta była wręcz powszechna. Ponieważ mamy tu konstrukcję nominativus cum infitivo, czasownik dinosco może występować w niej w różnych formach osobach i liczbach (i to może sprawiło kłopot szukającemu jej D. Sikorskiemu). Musiała być popularna w kancelarii papieskiej już przed ok. 800 r., o czym świadczy wielka liczba podobnych wzmianek w Liber diurnus, a nie brak też ich w Pseudo-Izydorze. Przypomnieć też trzeba, że w kancelariach papieskiej i cesarskiej była używana identyczna konstrukcja oparta na synonimicznym słowie video ${ }^{21}$. Na przykład Jan XIII pisał $\mathrm{w}$ jednym $\mathrm{z}$ dokumentów quibus preesse dinoscitur (971), a w innym cui

${ }^{20}$ Za uzupełnienia i aktualizacje notariusza HI uznać natomiast należy dwie nadwyżki przywileju Ottona III w stosunku do dokumentu papieskiego: scilicet prope occidentalem ripam Rochilinze, et sic oraz ob hoc diximus in occidentali plaga quia multae villae pertinent ad orientales urbes.

${ }^{21} \mathrm{~W}$ starożytności video $\mathrm{w}$ tego rodzaju konstrukcji było używane $\mathrm{w}$ nieco innym znaczeniu (,zdaje się”). Natomiast dinosco jako czasownik do budowy konstrukcji NCI sięga czasów starożytnych, zob. internetowy słownik klasyczny: Latin Word Study Tool (http:// www.perseus.tufts.edu/hopper/searchresults?q=dinoscitur\&target=la). 
preesse videris $(972)^{22}$. Mimo powszechności tej konstrukcji i predylekcji do niej skriniariusza Stefana uważam, że zwrot cui venerabilis episcopus Burcardus preesse dinoscitur przedostał się do dokumentu miśnieńskiego raczej z kancelarii cesarskiej za pośrednictwem supliki lub innej zapiski dostarczonej kancelarii papieskiej dla zredagowania fragmentu o granicach i innych lokalnych elementach. Była to po prostu jedna $\mathrm{z}$ najpospolitszych w tych czasach formuł na określenia biskupa.

Chociaż Dariusz Sikorski wytoczył szereg zarzutów przeciwko autentyczności przywileju Jana XIII dla Miśni z 2 I 968 r., to jednak nie widzę podstaw, aby w autentyczność tę wątpić. Okazuje się, że zachowują swoją moc moje poprzednie argumenty, a porównanie bulli z dokumentami cesarskimi Ottona I (971), Ottona II (983) i Ottona III (995) nie pozostawia wątpliwości, iż to dwa ostatnie dokumenty cesarskie były zależne od dokumentu papieskiego, a nie odwrotnie. Notariusz Ottona II przeredagował i uprościł postanowienia przywileju papieskiego w sprawie dziesięcin, a notariusz HI w 995 r. wiernie przepisał te postanowienia z dokumentu papieskiego, nie korzystając z dokumentu Ottona II z 983 r. Notariusz ten dostosował też do nowej sytuacji ideologię imperialną z czasów koronacji Ottona II, znajdującą odbicie w bulli Jana XIII, powstałej tydzień po tym doniosłym dla Liudolfingów wydarzeniu.

\section{Nochmals zur Echtheit der Urkunde Johannes' XIII. für das Bistum Meißen vom 2. Januar 968}

\section{Zusammenfassung}

Der Beitrag stellt eine Antwort auf die Polemik von Dariusz Sikorski dar, der eine Unmenge von Argumenten und kritischen Bemerkungen gegen die These von der Echtheit des Privilegs Johannes'XIII. vom 2. Januar 968, mit dem die Exemtion des Bistums Meißen verliehen worden war, ins Feld führte. Sikorski meint, daß es sich bei dieser Urkunde um eine Fälschung aus der ersten Hälfte des 12. Jahrhunderts handele. Der Verfasser bekräftigte alle bisher beigebrachten Befunde, darüber hinaus brachte er neue Argumente bei, die sich aus der Analyse der Privilegien der Kaiser Otto II. von 983 (DD O II 184) und Otto III. von 995 (DD O III 186) ergaben. Die gemeinsamen Elemente in diesen beiden kaiserlichen und in dem päpstlichen Privileg sprechen keineswegs gegen die Echtheit der Meißner Bulle. Im Gegenteil, sie beweisen gar ihre Echtheit. Denn wenn man - dem Gedankengang D. Sikorskis folgend - die Meißner Bulle für falsch hielte, müßten die gemeinsamen Textpassagen in den beiden Urkunden daraus resultieren, daß dem Notar, der die Urkunde Ottos III. redigierte, die Urkunde Ottos II. als Vorlage diente. Es stellte sich aber heraus, daß man die Urkunde Ottos III. trotz der gemeinsamen Textstellen auf keinen Fall aus dem erwähnten Privileg Ottos II. ableiten kann. Letztere Urkunde entstand u. a. durch die Auswertung der päpstlichen Bulle für Meißen, wobei der die Zehnten betreffende Teil vereinfacht, aktualisiert und ergänzt worden war. Der Schreiber der Urkunde Ottos III. schrieb hingegen zu einem großen Teil das päpstliche Privileg getreulich ab und ließ die Vereinfachungen, Aktualisierungen und Ergänzungen, die im Privileg Ottos II. gemacht worden waren, gänzlich weg. Die gemeinsamen Textpassagen in den Urkunden Ottos II. und Ottos III. entstanden also aufgrund einer gemeinsamen Vorlage, des päpstlichen Privilegs für Meißen. Der Verfasser zeigte ebenfalls auf, daß die inhaltlichen Unterschiede zwischen der Urkunde Ottos III. von 995 und der päpstlichen Bulle von 968 ebenfalls für die Echtheit dieses Privilegs sprechen.

Übersetzt von Waldemar Könighaus

${ }^{22}$ Papsturkunden, t. I, nr 207, 218. 


\title{
More on the authenticity of John XIII's document of 2 January 968 for the bishopric of Meissen
}

\begin{abstract}
The paper is a response to the polemic by Dariusz Sikorski, who put forward a number of arguments against the thesis about the authenticity of John XIII's bull of 2 January 968, which founded an exempted bishopric in Meissen. Sikorski believes that the document is a forgery produced in the first half of the $12^{\text {th }}$ century. This response to the polemic is divided into three parts: the first one lists examples showing that Sikorski's objections are unreliable; in the second part the most important arguments for the authenticity of the papal document are defended once again; the third one presents new proofs for the same thesis. The authors also draws attention to the similarity of the bull to the imperial documents of Otto II of 983 (DD O II 184) and Otto III of 995 (DD O III 186), and arguments that they do not contradict its authenticity but - quite to the contrary - confirm that authenticity, because the authors of the imperial documents used the text of the bull, not vice versa. Therefore, there is no reason to question the authenticity of the papal document of 968 .
\end{abstract}

